Jurnal Farmamedika Vol. 6, No. 1 Juni 2021

\title{
KARAKTERISASI PRODUKSI RHAMNOLIPID MENGGUNAKAN PENDEKATAN BIOLOGI SINTETIK
}

\author{
Nina Imaniar ${ }^{*}$, Tati Kristianti ${ }^{2}$, Sony Suhandono ${ }^{2}$ \\ ${ }^{1}$ Sekolah Tinggi Teknologi Industri dan Farmasi Bogor, Jalan kumbang No 23 Kota Bogor \\ ${ }^{2}$ Program Studi Pasca Sarjana, Sekolah Ilmu Teknologi Hayati Institut Teknologi Bandung \\ Korespondensi: imaniarsttifbogor@gmail.com
}

\begin{abstract}
ABSTRAK
Ketersediaan cadangan minyak mentah yang minim di Indonesia menjadi dasar dari penelitian ini untuk membuat sebuah inovasi baru yang dapat diterapkan dalam teknik enhanced oil recovery menggunakan agent biologi rekombinan. Agen tersebut di desain sebagai penghasil rhamnolipid yang dapat meningkatkan volume ekstraksi minyak mentah dari dalam kilang minyak. Tujuan penelitian ini adalah mengkarakterisasi rhamnolipid rekombinan yang dihasilkan melalui pendekatan biologi sintetik Gen pengkode Rhamnolipid (RhlAB) di insersikan ke dalam pUC57 dibawah kontrol promoter T7. Hasil analisis kuantitatif menunjukan konsentrasi rhamnolipid tertinggi di peroleh setelah inkubasi selama 15 jam di dalam medium pertumbuhan Luria Bertani dengan $\mathrm{pH} 7$ dan temperature pertumbuhan $37^{\circ} \mathrm{C}$, sedangkan analisis kualitatif menunjukan bahwa rhamnolipid rekombinan juga memiliki kemampuan untuk menurunkan tegangan permukaan dan memiliki aktivitas drop collapse. Kesimpulan penelitian ini adalah metode biologi sintetik dapat digunakan untuk memproduksi rhamnolipid rekombinan dengan aktivitas serupa dengan rhamnolipid yang di hasilkan dari species aslinya.
\end{abstract}

\section{Kata kunci : Rhamnolipid, Biologi Sintetik, MEOR}

\begin{abstract}
The availability of crude oil reserves in Indonesia is the basis of this research to create a new innovation that can be applied to enhance oil recovery using recombinant biological agents. The agent is designed to produce rhamnolipid which can increase the volume of crude oil extracted from oil mill. The aim of this study was to characterize the recombinant rhamnolipid produced through a synthetic biology approach. The gene encoding Rhamnolipid (RhlAB) was inserted into pUC57 under the control of the T7 promoter. The results of quantitative analysis showed that the highest rhamnolipid concentration was obtained after incubation for 15 hours in Luria Bertani growth medium with a pH of 7 and a growth temperature of $37^{\circ} \mathrm{C}$. Meanwhile, the qualitative analysis showed that the recombinant rhamnolipid also had the ability to reduce surface tension and had drop-collapse activity. The conclusion of this study is that synthetic biological methods can be used to produce recombinant rhamnolipids with activities similar to those of the original species.
\end{abstract}

\section{Keywords : Rhamnolipid, Synthetic Biology, MEOR}

\section{PENDAHULUAN}

Populasi masyarakat yang terus mengalami peningkatan berdampak pada lonjakan kebutuhan bahan bakar khususnya yang berasal dari minyak bumi. Di ketahui bersama, bahwa minyak bumi merupakan salah satu bahan alam yang tidak dapat di perbaharui sehingga proses ekplorasi dan eksploitasinya di batasi mengingat jumlahnya yang semakin menipis.
Pada kenyataannya, data yang diperoleh dari Kementrian ESDM menunjukan bahwa proses eksplorasi cadangan minyak nasional di dalam reservoir baik pada area onshore maupun offshore belum dilakukan secara maksimal. Hal ini dikarenakan pertimbangan biaya produksi yang semakin meningkat. apabila kegiatan eksplorasi tersebut diteruskan hingga ke tahap eksplorasi tersier. Biaya produksi yang tidak 
seimbang dengan outcome menyebabkan perusahaan tambang minyak menghentikan kegiatan eksploitasi pada tahapan tertentu dan cenderung untuk membuka reservoir baru dibandingkan terus melakukan eksploitasi pada reservoir tua.

Peningkatan eksploitasi minyak mentah dari dalam reservoir tua terus diupayakan untuk meminimalkan pembukaan reservoir baru yang akan berdampak pada pengeluaran biaya produksi yang tinggi. Beberapa metode yang dikembangkan untuk mengatasi permasalahan tersebut diantaranya menggunakan agen biologis yang dapat memproduksi senyawa biosurfaktan rhamnolipid [1].

Rhamnolipid merupakan senyawa ampifilik yang dapat menurunkan tegangan permukaan. Berdasarkan karateristik unik tersebut maka rhamnolipid dijadikan sebagai salah satu bahan untuk memaksimalkan penarikan minyak mentah dari dalam reservoir atau yang sering di sebut dengan istilah EOR.

Di alam, species yang sering di gunakan untuk produksi rhamnolipid adalah pseudomonas aeruginosa sp. Mikroba tersebut menjadi kandidat utama dikarenakan berdasarkan penelitian terdahulu mengatakan bahwa species ini dapat menghasilkan rhamnolipid dengan konsentrasi terbanyak di bandingkan species lainnya [2]. Namun, jika di lihat dari aspek toksisitas, Pseudomonas sp merupakan species yang bersifat pathogen terhadap manusia [3]. Dikarenakan sifat pathogen inilah maka dilakukan proses rekayasa genetik menggunakan pendekatan biologi sintetik yaitu dengan cara memindahkan gen produksi Rhamnolipid (RhlAB) dari pseudomonas aeruginosa ke host lain yaitu E.coli dengan beberapa pertimbangan diantaranya untuk mengurangi dampak pathogen serta mempermudah proses rekayasa dikarenakan E.coli merupakan host yang telah banyak digunakan sebagai host rekombinan [4].

Pada penelitian ini, untuk mendapatkan konsentrasi optimum rhamnolipid yang di hasilkan oleh E.coli rekombinan, maka dilakukan optimasi pada beberapa variable yaitu $\mathrm{pH}$ pertumbuhan, lama waktu inkubasi serta temperature selama masa inkubasi. Selain itu, dilakukan pula karakteristik rhamnolipid yang dihasilkan sebagai skrining awal untuk menentukan aktivitas rhamnolipid yang dihasilkan.

\section{METODE PENELITIAN}

Bahan

Gen pengkode rhamnolipid yang digunakan merupakan gen sintetik yang telah di optimasi dan di kemas dalam plasmid pUC57. Promoter menggunakan T7, dan gen pengkode rhamnolipid menggunakan gen RhlA dan RhlB serta di akhiri dengan terminator. Plasmid tersebut di rancang menggunakan antibiotic ampicillin untuk membantu proses seleksi pada saat cloning. Primer spesifik RhlAB digunakan untuk evaluasi PCR serta E.coli rekombinan di gunakan sebagai host pada saat cloning dan produksi rhamnolipid. Minyak mentah sebagai sampel uji di peroleh dari Lembaga Minyak dan Gas (LEMIGAS) Indonesia. Tween 80\% sebagai control positif rhamnolipid rekombinan.

\section{Alat}

Spektrofotometer UV-VIS, Mesin PCR, mesin elektroforesis, Centrifuge, $\mathrm{pH}$ meter, peralatan gelas.

\section{Metode}

Plasmid pUC57 yang membawa gen sintetik rhamnolipid di transformasikan ke dalam E.coli dh5 alpha untuk di cloning menggunakan metode lisis alkaline. Hasilnya kemudian di skrining menggunakan antibiotic ampicillin, di lanjutkan dengan skrining PCR menggunakan primer spesifik terhadap gen of interest. Plasmid pUC57 yang telah terkonfirmasi kemudian di transformasi ke dalam E.coli BL21 untuk produksi rhamnolipid.

\section{Produksi Rhamnolipid dan Analisis Kuantitatif}

E. coli rekombinan lalu di inkubasi menggunakan media pertumbuhan Luria Bertani. Selama masa inkubasi, di lakukan analisis kuantitatif dengan beberapa parameter uji yaitu masa inkubasi dengan cara pengambilan sampling setiap 3 jam sekali selama 24 jam untuk determinasi konsentrasi rhamnolipid yang dihasilkan. Selain itu, di lakukan pula optimasi pH medium pertumbuhan pada $\mathrm{pH} 5$ hingga 9 dan temperature inkubasi pada 25,37 dan $45^{\circ} \mathrm{C}$. Masing-masing parameter dilakukan dengan dengan 3 kali pengulangan. Proses ekstraksi rhamnolipid selama analisis kuantitaif menggunakan metode ekstraksi methylene Blue 
Solution berdasarkan protokol yang telah di kerjakan oleh Rasamiravaka dkk [5].

\section{Analisis Kualitatif}

Analisis kualitatif dilakukan untuk uji aktifitas rhamnolipid rekombinan. Uji tersebut dilakukan menggunakan dua cara yaitu drop collapse assay setiap 3 jam sekali selama 24 jam serta uji tegangan permukaan yang di lakukan pada berbagai titik suhu yaitu $4,25,35$, dan $90^{\circ} \mathrm{C}$.

\section{HASIL DAN PEMBAHASAN}

Surfaktan merupakan senyawa kimia yang memiliki karakteristik dapat menurunkan tegangan permukaan antara dua cairan, antara gas da cairan atau antara caiaran dan zat padat. Senyawa tersebut dapat bertindak sebagai deterjen, pengemulsi maupun agen pembusa.

Rhamnolipid merupakan salah satu jenis surfaktan yang di hasilkan oleh beberapa spesies bakteri di antaranya Pseudomonas aeruginosa. Berdasarkan hasil penelitian dari berbagai sumber, rhamnolipid memiliki sifat dapat menurunkan tegangan permukaan. Berdasarkan karakteristik tersebut maka rhamnolipid sering dijadikan sebagai bahan untuk meningkatkan jumlah minyak yang di tarik dari reservoir.

Pseudomonas aeruginosa merupakan species bakteri yang bersifat pathogen terhadap manusia. Bakteri ini diketahui dapat mengakibatkan gangguan pada sistem pernapasan manusia [6]. Di sisi lain, rhamnolipid yang di hasilkan oleh Pseudomonas aeruginosa hingga saat ini dilaporkan memiliki konsentrasi tertinggi jika di bandingkan dengan species lainnya yang juga di ketahui memiliki kemampuan untuk menghasilkan rhamnolipid. Di sebabkan oleh faktor pathogenisitas tersebut sehingga di lakukan proses rekayasa genetic melalui pendekatan biologi sintetik dengan memindahkan gen pengkode rhamnolipid dari Pseudomonas aeruginosa ke bakteri lain yan memiliki tingkat pathogen lebih rendah yakni E.coli.

Gen pengkode rhamnolipid adalah gen RhlA, RhlB dan RhlC. Gen RhlA dan RhlB diketahui dapat menghasilkan enzim monorhamnolipid sedangkan gen RhlC dapat menghasilkan enzim di-rhamnolipid. Pada penelitian ini, hanya menggunakan gen RhlA dan RhlB sehingga hanya dapat memproduksi monorhamnolipid.
Evaluasi hasil transformasi gen sintetik rhamolipid yang di insersikan ke dalam vector pUC57, di konfirmasi menggunakan beberapa cara yaitu konfirmasi menggunakan seleksi antibiotic ampisilin, seleksi menggunakan enzim restriksi EcoRI dan pstI yang mengapit gen RhlAB serta seleksi menggunakan primer spesifik terhadap sekuens gen RhlAB. Hasil evaluasi pada gambar 1 menunjukan bahwa gen sintetik pengkode rhamnolipid berhasil tertransformasi ke dalam bakteri E.coli yang selanjutnya di sebut sebagai $E$. coli rekombinan.

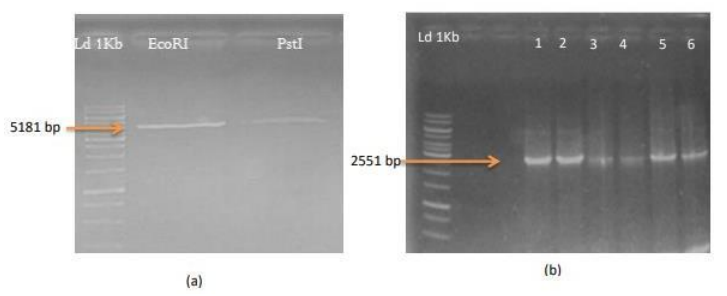

Gambar 1. Hasil konfirmasi pUC57 (a) Konfirmasi pemotongan pUC57 menggunakan enzim restriksi EcoRI pada sumur 1, pstI pada sumur 2 (b) Konfirmasi PCR pada pUC57 menggunakan primer spesifik yang komplemen terhadap gen pengkode rhamnolipid pada sumur 1-6.

Selanjutnya, untuk mengetahui waktu panen terbaik yang menghasilkan rhamnolipid dengan kuantitas terbanyak maka di lakukan kultivasi atau perbanyakan selama 24 jam dengan 3 kali pengulangan. Di dapatkan bahwa jam ke 15 setelah inkubasi menjadi waktu optimum untuk pemanenan rhamnolipid di karenakan konsentrasi pada waktu tersebut menghasilkan rhamnolipid dengan konsentrasi terbanyak.

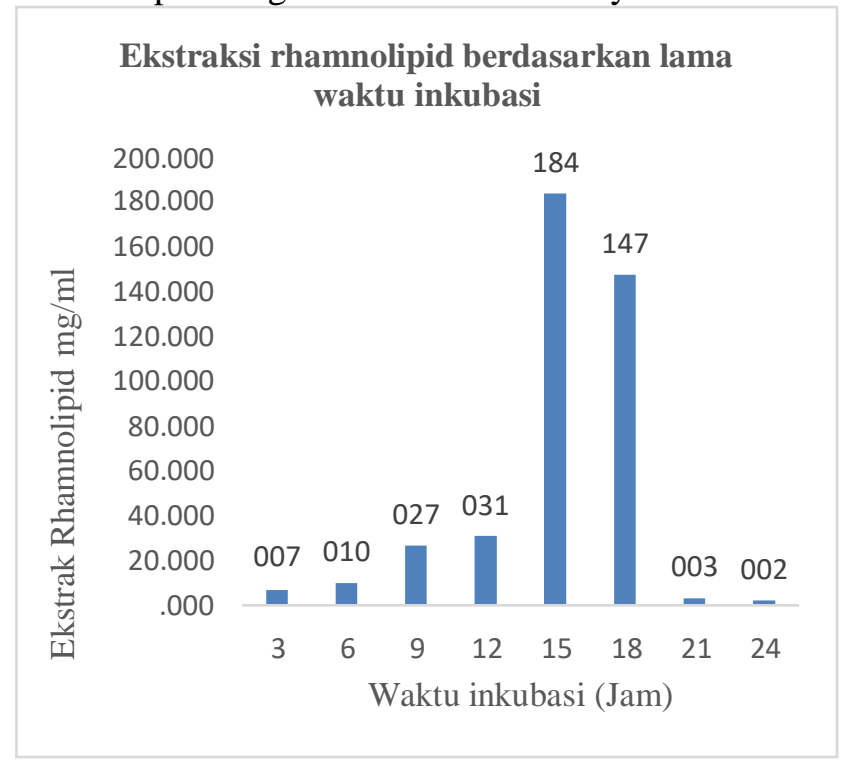


Gambar 2. Kurva analisis konsentrasi rhamnolipid selama 24 jam yang ditumbuhkan pada medium Luria Bertani tanpa penambahan IPTG.

Ketika di cocokan dengan kurva tumbuh E.coli rekombinan data tidak di tampilkan maka di peroleh bahwa jam ke 15 hingga ke 18 merupakan fase lag atau fase stationer dari E. coli rekombinan. Hal tersebut sesuai dengan teori yang menyatakan bahwa fase stationer menjadi fase terbaik untuk produksi metabolit sekunder. Sehingga dapat di jadikan sebagai acuan untuk di lakukan pemanenan untuk memperoleh hasil yang tinggi.

Selain waktu panen terbaik, di peroleh $\mathrm{pH}$ pertumbuhan terbaik untuk menghasilkan rhamnolipid dari E.coli rekombinan yaitu berada pada $\mathrm{pH} 7$ dengan nilai konsentrasi rhamnolipid sebesar $234,142 \mu \mathrm{g} / \mathrm{ml}$ yang dapat di lihat pada gambar 3. Hal ini terjadi di karenakan $\mathrm{pH}$ optimum yang dapat mendukung produksi enzim rhamnolipid adalah berada pada $\mathrm{pH}$ netral, sedangkan $\mathrm{pH}$ yang terlalu asam dan terlalu basa dapat menurunkan produksi enzim rhamnolipid [7].

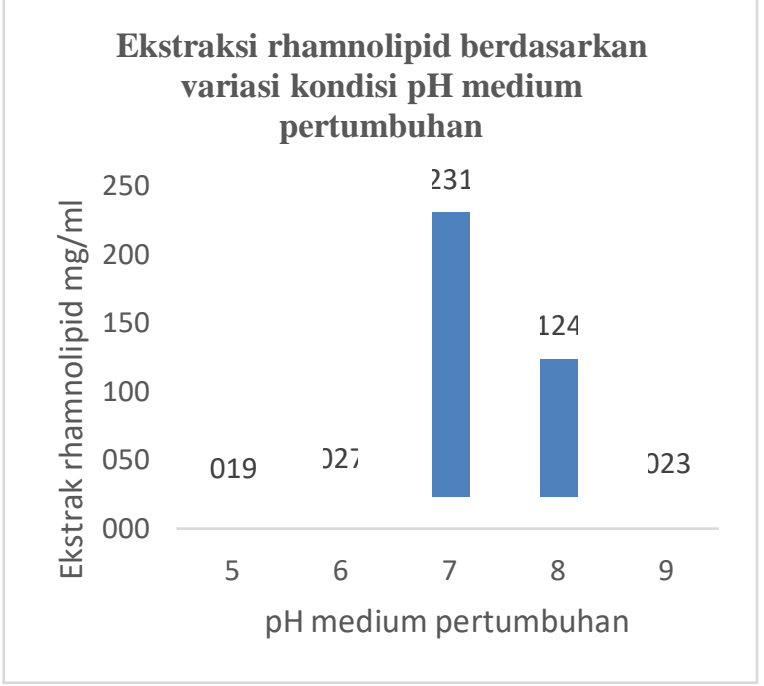

Gambar 3. Kurva analisis kondisi $\mathrm{pH}$ optimum untuk medium pertumbuhan E.coli rekombinan

Pada optimasi suhu, proses ekstraksi dilakukan setelah umur inokulum mencapai jam ke 15 setelah inkubasi dan $\mathrm{pH}$ medium pertumbuhan pada $\mathrm{pH} 7$ untuk keseragaman perlakuan. Suhu $45^{\circ} \mathrm{C}$ menjadi suhu pertumbuhan dengan produksi rhamnolipid terkecil yaitu 19,85 $\mu \mathrm{g} / \mathrm{ml}$, selanjutnya diikut oleh suhu $25^{\circ} \mathrm{C}$ dan $37^{\circ} \mathrm{C}$ dengan nilai berturut turut sebesar 47,95 $\mu \mathrm{g} / \mathrm{ml}$ dan $202,35 \mu \mathrm{g} / \mathrm{ml}$.
Berdasarkan beberapa penelitian terdahulu mengenai optimasi produksi rhamnolipid dikemukakan bahwa suhu $37^{\circ} \mathrm{C}$ menjadi suhu optimum untuk proses biosintesis rhamnolipid [8] dan E.coli pun akan tumbuh dengan optimum pada suhu $37^{\circ} \mathrm{C}$.

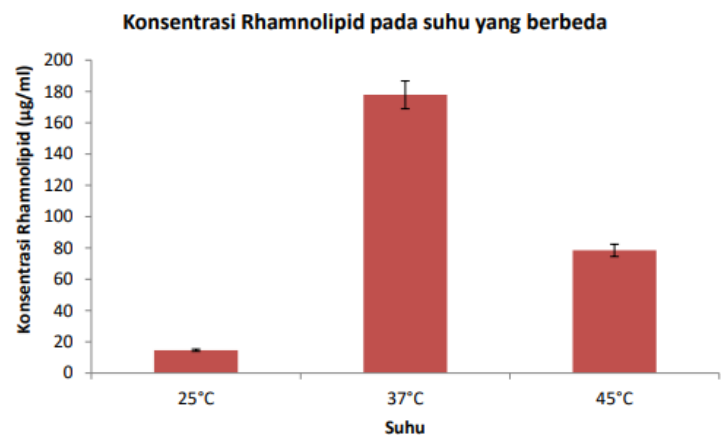

Gambar 4. Kurva analisis kondisi suhu optimum untuk medium pertumbuhan E.coli rekombinan

Rhamnolipid merupakan senyawa yang dapat menurunkan tegangan permukaan karena memiliki properti yang unik berupa ekor hidrofobik dan kepala hidrofilik sehingga dapat memudahkan proses pengangkatan minyak bumi dari dalam reservoir. Penelitian yang berkelanjutan tentang rhamnolipid mengemukakan bahwa terdapat sebuah korelasi antara struktur rhamnolipid dan karakter fluida didalam reservoir yang dapat mengakibatkan terjadinya proses recovery (9).

Pada penelitian ini, digunakan silwet (surfaktan sintetik) sebagai kontrol positif, dan air sebagai kontrol negatif. Dari hasil yang di jelaskan pada gambar 4.9 dapat dilihat bahwa pada temperatur tinggi yaitu $90^{\circ} \mathrm{C}$, rhamnolipid yang dihasilkan dapat memberikan nilai tegangan permukaan yang terbaik yaitu berada pada nilai 23,67 Dyne/cm yang memiliki pengertian bahwa yang bekerja untuk menurunkan tegangan permukaan per tiap $\mathrm{cm}$ lapisan minyak dan air dalam percobaan ini adalah sebanyak 23,67 Dyne.

Berbeda dengan yang disampaikan oleh peneliti lain yang melakukan analisis IFT pada Pseudomonas aeruginosa dimana semakin tinggi suhu akan memberikan nilai IFT yang semakin tinggi Hal tersebut diasumsikan terjadi karena jenis rhamnolipid. 


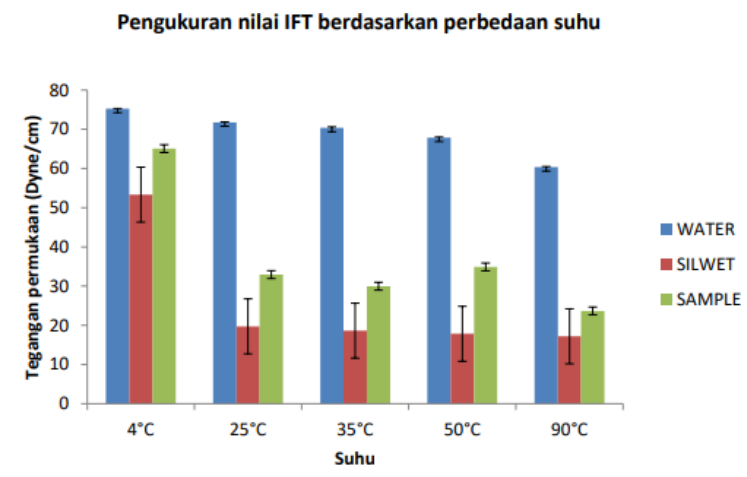

Gambar 5. Kurva analisis kemampuan menurunkan IFT berdasarkan perbedaan suhu.

\section{KESIMPULAN}

Melalui pendekatan biologi sintetik dapat dihasilkan rhamnolipid dari bakteri non indigenous yaitu E. coli. Setelah di lakukan karakterisasi, diperoleh rhamnolipid dengan kemampuan menurunkan tegangan permukaan walaupun tak sebaik pada species aslinya. Hal ini perlu di lakukan pengkajian ulang, semisal pada optimasi kodon hingga optimasi subtrat pertumbuhan, temperature, $\mathrm{pH}$ dan waktu inkubasi pada host rekombinan.

\section{UCAPAN TERIMA KASIH}

1. TIM IGEM ITB 2014 atas design vector produksi rhamnolipid

2. Lembaga Pengelola Dana Pendidikan (LPDP) atas bantuan dana berupa beasiswa pascasarjana hingga penulis dapat menyelesaikan studi pascasarjana di SITH ITB

\section{DAFTAR PUSTAKA :}

1. Walter, V., Syldatk, C., Hausmann, R. 2013. Screening Concept for the Isolation of
Biosurfactant Producing Microorganisms. Biosurfactants. 1-13

2. Soares, A., S., Pereira, N., Freire, D, M, G. 2016. Stratrgies for improved rhamnolipid production by Pseudomonas aeruginosa PA1. Peer Journal. 4:e2078

3. Brian, et al. 2019. Chatelicidin is a"fire alarm' generating protective NLRP3-dependent airway epithelial cell inflammatory responses during infection with Pseudomonas aeruginosa. Plos Pathogen

4. Nguyen, M, T. 2006. The effect of temperature on the growth of the bacteria Escherichia coli DH5a. Saint Martin University Journal. Vol. I.

5. Rasamiravaka, T., Vandeputte, O., El Jaziri, M. 2016. Procedure for rhamnolipid quantification using methylene blue, Bioprotocol Vol.6 (7)

6. Virgi, L., Katar, Y., Bahar, E. 2016. Identifikasi Bakteri Infeksi Saluran Pernafasan Bawah (Non TB) dan Pola Resistensinya pada Penderita Diabetes Melitus di RSUP M. Jamil. Jurnal Kesehatan Andalas 2016. 5(3)

7. Jamal, et al. 2014. Enhanced Production of Rhamnolipids by Pseudomonas aeruginosa JQ927360 Using Response Surface Methodology. Asian Journal of Chemistry Vol 26 (4).

8. Muller, M, M., Horman, B., Kugel, M., Syldatk, C., Hausmann, R. 2011. Evaluation of Rhamnolipid production capacity of Pseudomonas aeruginosa PAOI in comparison to the rhamnolipid over producer strains DSM 7108 and DSM 2874. Applied Microbiology and Biotechnology, 89(3): 585-92.

9. Bourell, M., Schechter, R,S. 1988. Microemulsions and related systems, formulation, solvency, and physical properties. Surfactant Science Series, vol. 30 